\title{
Importance of Managerial Accounting from High Growth Online Company Valuation Perspective
}

\author{
Jan Pekar
}

\begin{abstract}
:
Young, high growth internet/online companies are an attractive topic for market analysts and hot shots of Initial Private Offerings. At the same time, it is very complicated to provide a robust valuation for such companies, as shown by often unpredictable paths of share prices, resulting in the dot.com bubble burst in the past. This paper aims to explain why traditional valuation techniques fail to identify the value of a company with a fair degree of probability and tries to identify new metrics reported by managerial accounting that should be included in the valuation procedure. Assuming the condition of technological interchangeability of processes and practices, the presented paper concludes that using the New Economy specific metrics, such as traffic and various conversion factors explaining top-line traffic monetization, it is possible to adopt a conventional valuation technique, i.e. the DCF, with a very high degree of confidence for the incremental revenue and profit estimations. The interchangeability is also a proof of an innovative potential of the newly introduced technologies and explains the high frequency of strategic acquisitions on this market. Needless to say, the key information sources for valuation of companies under consideration are not financial statements, but managerial records instead, especially web analytics and search algorithm entries.
\end{abstract}

Key words: Online company valuation; High growth start-up valuation; Online business metrics.

JEL classification: G32, M40.

\section{Introduction}

"Valuing firms even in the best of conditions is a difficult exercise. But valuing firms in the internet business is extremely difficult" (Gupta \& Chevalier, 2002). Absence of flawless numerical techniques creates a space for behavioural influence, fashion and hype that can lead to periods of significant mispricing, with the gravest known example being the dot-com bubble.

Ofek and Richardson (2001) show that Internet firms valuation was roughly 35 revenue multiple at the end of 1999, which implied $605 \mathrm{P} / \mathrm{E}$ ratio, had the companies achieved industry average net income margins. The dot.com hey-days

Jan Pekař University of Economics, Prague, Faculty of Finance and Accounting, Department of Finance and Business Valuation, W. Churchill Sq. 4, 13067 Prague, Czech Republic; <xpekj09@vse.cz>.

The article is processed as an output of the research project under the institutional support VŠE IP100040 of the Faculty of Finance and Accounting, University of Economics, Prague. 

Perspective.

are over, yet both the recent primary and secondary market movements show that the taste of the investment universe is very favourable towards online companies.

Nevertheless, the segment had to overcome the after-bubble scepticism and risks associated with the dot.com business are under a thorough scrutiny. Soto-Acosta and Meroño-Cerdan (2008) questioned the internet technology contribution to value creation and found out that Internet technology by itself rarely creates an ebusiness value, yet they confirm that Internet resources play a critical role in the creation of e-business capabilities that are key drivers of the e-business value. Even critics of the New Economy firms, including Higson and Briginshaw (2000), admit that the Internet is creating new markets and radically re-engineers many old ones.

An online technology company is often an innovative start-up, which fact makes its valuation a very complex task due to the inapplicability of certain standard methods. Such a company combines the characteristics of several sectors, which typically include information technology, consumer staples, and consumer discretionary. Rules of thumb and market multiples are hard to identify, since different sectors overlap with blurred lines. Many such companies are subjected to valuation while recording high growth, but still negative earnings. The term "high growth" was first defined by David Birch (1979) as an annual growth higher than $20 \%$ p.a. in three consecutive years. Despite dramatic changes in market layout and further deepening of globalization, this definition is still applied by OECD. Due to difficulty in adoption of some of the standard valuation techniques, market value of such companies is often more sensitive to savvy marketing tools employed by venture capitalists and underwriters who manage to create investor demand and boost the valuation. Such trend is identifiable on the cases of highvalued IPOs that tend to underperform in the long-run as valuation premia converge towards the peer levels. Due to higher levels of uncertainty and overconfidence, IPOs with negative income seem to be different and more exposed to the marketing hype than other types of IPOs (Zörgiebel, 2016).

Although innovative often means specific, only inevitable degree of subjective judgement is desirable and a diligent valuation must always be performed. New Economy companies may require application of new methods or focus on previously neglected hard metrics. These new metrics, such as the number of unique visitors per page, were often called responsible for the dot.com bubble burst. Nevertheless, Demers and Lev (2001) confirmed that such metric can predict the value of a company share price both before and after the bubble burst.

Managerial accounting is primarily a tool for company's internal management. Well-kept records thus identify and track elements considered by the company management crucial for its commercial success as well as itsvalue drivers 
irrespective to their specific form. This paper aims to examine whether managerial accounting statements as a material source of information increase the explanatory power of traditional methods of company valuation that, based solely on available financial statements, would otherwise be hardly applicable in the case of young, high growth online companies.

\section{Metasearch and Online Reseller}

In 1983, The Times magazine introduces the cover article "The New Economy" by C. P. Alexander. The term has since been used to describe new, high-growth industries that are on the cutting edge of technology and represent the driving force of economic growth. The new economy is commonly believed to have started in the late 1990s as the high-tech tools, such as the internet and increasingly powerful computers, began penetrating the consumer and business marketplaces.

Rosner (2013) identifies two basic types of internet companies: those using modern, online channels to sell goods or services, and Internet portals that have various revenue streams, including those from advertising.

The presented paper will analyse one specific type of internet business, nowadays extremely popular and attractive from the investors' perspective - metasearches and online resellers.

A metasearch engine (or aggregator) is a search tool that uses another search engine's data to produce its own results from the Internet (Berger, 2005). The metasearch engine is a technology core of both the Metasearch and Online reselling businesses. The following chart provides basic description of the process. The search engine integrates several databases via Application Programming Interface (API) and then employs a sophisticated search algorithm to deliver the best results under specific search criteria. The best results are then presented to the customer.

\section{Fig. 1 Search scheme}

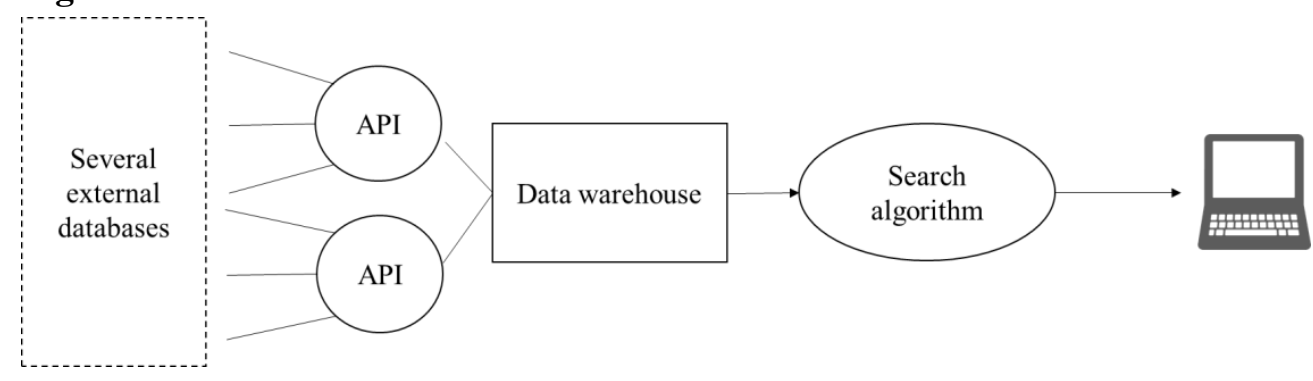

Source: Authorial illustration. 

Perspective.

Metasearch and reselling operational models may seem identical to the customer. The most important feature they share is that both types of internet pages sell something that was not created by the operator of the web page itself. Both are fully dedicated to their respective businesses and do not serve as a forum, social platform, etc. Air tickets search and purchase is a good example of the examined type of businesses and as such it will be used for further illustrations.

\section{Tab. 1 Metasearch and online reseller}

\begin{tabular}{|c|c|c|}
\hline Characteristic & Metasearch & Online reseller \\
\hline Operational model & $\begin{array}{l}\text { Aggregates market data and } \\
\text { identifies the best option based on } \\
\text { the search criteria. Redirects } \\
\text { customers to merchants' pages (air } \\
\text { carrier) and afterwards is paid a } \\
\text { commission, affiliate fee. }\end{array}$ & $\begin{array}{l}\text { Aggregates market data and } \\
\text { identifies the best option based on } \\
\text { the search criteria. Buys a ticket on } \\
\text { its own cost, adds a margin and } \\
\text { sells directly to a customer. }\end{array}$ \\
\hline Product & Optimal search result & Air ticket(s) for an optimal route \\
\hline Type of income & $\begin{array}{l}\text { Commission Affiliate fee (per click } \\
\text { or } \% \text { of the ticket's value) }\end{array}$ & Sale of tickets \\
\hline Profit margin & Very high (up to $90 \%$ ) & $\begin{array}{l}\text { Very low - homogenous products } \\
\text { limit the add-on margin potential, } \\
\text { very high variable costs. }\end{array}$ \\
\hline $\begin{array}{l}\text { Accounts } \\
\text { receivable } \\
\text { management }\end{array}$ & B2B relationships, usual invoicing & Paid upon issuance \\
\hline $\begin{array}{l}\text { Tangible fixed } \\
\text { assets value }\end{array}$ & Negligible & Negligible \\
\hline $\begin{array}{l}\text { Intangible fixed } \\
\text { assets value }\end{array}$ & Negligible & Negligible \\
\hline Core value source & $\begin{array}{l}\text { Intellectual capital and internally } \\
\text { generated unrecognizable assets }\end{array}$ & $\begin{array}{l}\text { Intellectual capital and internally } \\
\text { generated unrecognizable assets }\end{array}$ \\
\hline
\end{tabular}

Source: Authorial calculations.

Metasearches achieve high profit margins since they generate revenues with immaterial costs. Resellers, on the other hand, first need to purchase the "underlying" goods, thus incurring significant costs.

Both tangible and intangible fixed asset are negligible, especially in relation to the turnover, unless a company purchases part of its intellectual property from a thirdparty, due to strict conditions of recognition of internally generated assets, as further explained in the Chapter 3.2. Contemporary trends in ICT favour consuming shared cloud services (operational memory, computing power, licenses 
and tools) over investing into own hardware and software. Since there are no minimum lease payments and the consumer does not have a right to operate an asset but pays for a consumption of its output instead, this B2B relationship should not be classified as an operational lease and thus it shall not be handled as an asset and liability for the valuation purposes.

\subsection{Revenue generation}

Let us examine where the value of an internet reseller lies. Revenue is recognized when the company successfully sells the ticket. A customer nevertheless needs to make several steps to complete the transaction, starting with a visit to the site, thus generating traffic.

\section{Fig. 2 Revenue generation}

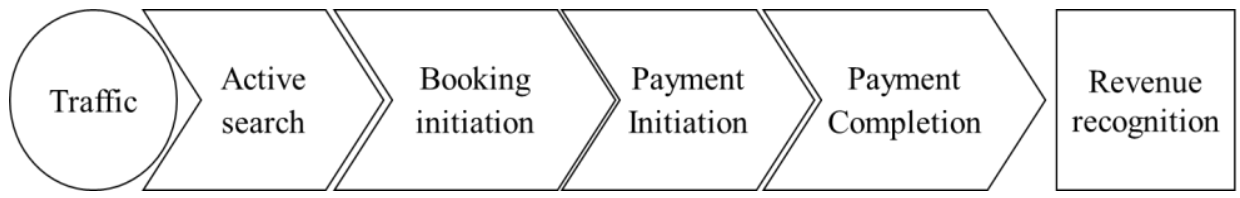

Source: Authorial illustration.

General formula for retailer's annual sales can be described as follows.

$$
\text { Completed payments } \times \text { Average price }=\text { Revenue, }
$$

Which can be further decomposed

$$
\begin{gathered}
\text { Audience } \times \frac{\text { Traffic }}{\text { Audience }} \times \frac{\text { Searches }}{\text { Traffic }} \times \frac{\text { Bookings }}{\text { Searches }} \times \frac{\text { Payments }}{\text { Revenue, }} \\
\text { Booking }
\end{gathered}
$$

Metasearch's road to revenue is shorter, because the booking session is open on web pages of the respective airline. Redirection of a customer to this page is a trigger for revenue recognition in the books.

$$
\text { Audience } \times \frac{\text { Traffic }}{\text { Audience }} \times \frac{\text { Searches }}{\text { Traffic }} \times \frac{\text { Bookings }}{\text { Searches }} \times \text { Avg.fee }=\text { Revenue, }
$$

\subsection{Role of conversion factors in online merchandise}

Conversion factors explain the ratio between the customer base and completed transactions. If every potential consumer who is aware of the web page's existence bought one flight, conversion factors would equal to one. Since all the components of conversion factors have a material impact on the revenue generation, they will be considered as value drivers. To maximise the total conversion factor, the company needs to reach excellence in many fields, as shown in the 3rd column. 
Pekař, J.: Importance of Managerial Accounting from High Growth Online Company Valuation Perspective.

Tab. 2 Value drivers

\begin{tabular}{|c|c|c|}
\hline Value driver & Description & Field \\
\hline $\begin{array}{l}\text { Audience/Customer } \\
\text { base }\end{array}$ & People aware of the web page existence & \\
\hline Traffic & $\begin{array}{l}\text { Number of prospective customers who load the landing } \\
\text { page }\end{array}$ & Marketing \\
\hline Searches & $\begin{array}{l}\text { Number of search commands executed by the page } \\
\text { visitors }\end{array}$ & \\
\hline Bookings & $\begin{array}{l}\text { Number of successful searches, i.e. initiated booking } \\
\text { sessions }\end{array}$ & Product \\
\hline Payments initiated & $\begin{array}{l}\text { Number of completed booking sessions, i.e. proceeds to } \\
\text { payment }\end{array}$ & $\begin{array}{l}\text { User experience } \\
\text { (UX) }\end{array}$ \\
\hline $\begin{array}{l}\text { Payments } \\
\text { completed }\end{array}$ & $\begin{array}{l}\text { Number of payments accepted by card acquirer, i.e. } \\
\text { completed transactions }\end{array}$ & Product \\
\hline Average price & Average price of a completed transaction & $\begin{array}{l}\text { Product, } \\
\text { Exogenous }\end{array}$ \\
\hline
\end{tabular}

Source: Authorial calculations.

The customer base is a very important metrics and sometimes it is the subject of an acquisition just by itself. The value pattern of an online company follows the pattern of the customer base size, as shown by research undertaken by Shapiro and Varian (1998). Those customers who visited the page within the examined time period (year, month, day) generate site traffic. The traffic is recorded relative to the revenues recorded in the respective time period to measure the Traffic monetization (earned dollar per unique visitor). Traffic is used since unlike audience, which defines number of people aware of the product, it represents a hard and precise measure of the number of people that actively visited the merchants' web page. The search results need to provide the customer with a favourable travel option to make him or her proceed to booking. Some booking sessions are yet not completed, since prospective customers do not trust the security or simply do not like the format of the booking page. The online business is global by definition, therefore resellers try to accept as many credit and debit card payments as possible. Acquiring fees and other parameters nevertheless differ with respect to the respective currency, territory and card issuer; therefore some payments are not accepted, sometimes even deliberately. The average price is mainly exogenous variable dependent on the customer's preferences, however it can be influenced by the search algorithm ("cheap" long-haul flights have a higher price than local, low-cost air shuttles) and by customer targeting (e.g. focus on business clientele and leisure flights). 


\section{Flaws of Standard Valuation Techniques}

Both scientific and professional papers mention importance of the discounted cash flow, relative and asset-based methodology. (Vydržel, Soukupová, 2012, Zwilling, 2016, Damodaran, 2009). These techniques have their flaws that become even more apparent in the case of young start-up companies. This is due to the fact that these young companies generate value from internally grown intellectual capital, i.e. knowledge that is of a particular value to the given organization, but not necessarily carried out in the company's balance sheet (Bassi, 1997).

\subsection{Market multiples}

Classical market multiples are $\mathrm{P} / \mathrm{E}, \mathrm{P} / \mathrm{EBITDA}, \mathrm{P} / \mathrm{S}$, and other ratios derived from an income statement of the analysed company. Many companies looking for venture funding are yet to generate even a single dollar. Relating a post or premoney valuation with sales would thus result in an infinite multiple. With no sales, it is hard to expect a positive EBITDA or earnings.

More mature companies already generate revenue, yet their earnings may remain negative. However, companies in revenue but not in profit are in demand from investors, some were even listed on the stock exchange, as examined by Zörgiebel (2016). Still, it is difficult to use the P/E ratio for a company that has zero or negative earnings (Gupta et al. 2004). These multiples thus cannot be taken for a diligent value estimator.

\subsection{Asset based approach to valuation}

Innovative means powered by intellectual capital. Intellectual capital driven proportion of the company value has significantly increased in the last decades all over the market. Analysis performed by Cardoza et al. (2006) showed material rise in intangible book value to the total book value among the S\&P index from $1.9 \%$ in 1975 to $43.2 \%$ in 2005 . At the same time, the share of intangible value to market capitalization rose from $16.8 \%$ to $79.7 \%$. Sector analysis shows that Consumer staples, Consumer discretionary and Information Technology rank among the top 5 intangible value driven sectors with $94 \%, 88 \%$ and $82 \%$, respectively. It is reasonable to assume that even higher proportion of the value of a company with no profit, no stable customer base and no tangibles will be attributable to intellectual capital.

Although accounting standards were amended several times to better reflect the value of intangibles in the books, the disproportion in the above mentioned ratios suggests that the true value of intangibles is scarcely recognized in the books. Internally generated intangibles often fail to meet the characteristics of an intangible asset, i.e. identifiability, control over the resource and existence of 

Perspective.

future economic benefits. If a cost expensed or a liability incurred cannot be allocated to an intangible asset, it must be recognized as an expense.

To simplify the recognition assessment, the standards require entities to classify their research, development, and other internal asset generation processes as either the research phase, or the development phase.

Activities covered in the research phase include obtaining new knowledge, search for alternative technologies, materials, or redesigning. No intangible asset ever arises from the research phase of a project, since future generations of economic benefits remain uncertain. All costs incurred shall be expensed immediately.

The development activities are further advanced; therefore entities can sometimes identify an intangible asset if they succeed to demonstrate the future flow of economic benefits attributable to this asset. Activities involved in the development phase are typically design, construction and testing of prototypes, operation of a pilot plant that cannot yet be run on commercial basis. Design of the final product for sale is also a development activity, as well as the implementation of researched advanced technology. One can say that general scientific research is never considered to be an asset, whilst implementation of a technology obtained by that research can be identified as an asset if further conditions are met.

Such asset can be recognized only if the entity is able to demonstrate the future economic benefit of the asset, which includes the feasibility of completing the asset so that it will be available for sale or operation, and also intention and capability of the entity of using or selling the asset. That means that the entity must prove that there is a relevant market for the output of the asset or the asset itself, or demonstrate the value created by the internal use of the asset by the company. The condition of ability to reliably measure related costs must be met as well, since intangible assets shall be recognized - initially measured - at cost. To measure the costs, the entity will most likely allocate costs incurred, such as salaries and programming licenses if talking about software development.

Moreover, recognition and treatment of internally generated intangible assets is a subject to different accounting frameworks.

The standards set by IFRS were designed to enforce a worldwide comprehensive standardized accounting system, whilst both the US GAAP and CAS are national regulations. ASC 350 Intangibles - Goodwill and Other, ASC 805 Business Combinations and ASC 730 Research and Development specify accounting for intangibles under US GAAP, whilst there is no separate category for intangible assets under CAS.

It is fair to say that companies reporting under US GAAP will report almost no internally generated intangible assets. Costs incurred during both the research and development phases shall be expensed immediately. Separable items can be 
recognized as intangibles under US GAAP as a result of an acquisition, irrespective of the fact whether the asset in question was previously reported by the acquirer. US GAAP directs entities to expense rather than capitalize all such expenses, which treatment they find favourable, since such expenses are tax deductible. Entity producing software, which is an exception, should account for an intangible asset only once the feasibility of the project is confirmed, i.e. when the future flow of the economic benefit is secured. In practice, companies such as Microsoft recognize software as economically feasible only a short period of time before the manufacturing stage. Intangible assets acquired due to a legal contract shall be accounted for and carried at the purchase price, with no revaluation allowed.

CAS regulations expressed in the Standard 013 - Long lived Tangible and Intangible Assets and Standard 38 - Intangible Assets are extremely loose. CAS requires an asset to have a useful life longer than one year and a value above the limit specified by the accounting unit itself. Research and development cannot be accounted for, unless obtained as a result of a legal action or held for sale. The carrying amount equals the initial price less accumulated impairment and amortization, with no revaluation allowed.

Let us summarize the main differences in recognition and treatment of internally generated intangible assets under the three examined frameworks.

\section{Tab. 3 Recognition and treatment of intangible assets}

\begin{tabular}{|c|c|c|c|}
\hline Definition & IFRS & US GAAP & CAS \\
\hline Intangible Assets & $\begin{array}{l}\text { Identifiable non- } \\
\text { monetary assets without } \\
\text { physical substance that } \\
\text { are under control of the } \\
\text { entity and promise future } \\
\text { flow of economic } \\
\text { benefits with reliably } \\
\text { measurable costs. }\end{array}$ & $\begin{array}{l}\text { Assets without physical } \\
\text { substance separable from } \\
\text { goodwill which promise } \\
\text { future flow of economic } \\
\text { benefits. }\end{array}$ & $\begin{array}{l}\text { List of items } \\
\text { Useful life longer } \\
\text { than } 1 \text { year, } \\
\text { carrying value } \\
\text { higher than a limit } \\
\text { set by the } \\
\text { accounting unit. }\end{array}$ \\
\hline $\mathrm{R} \& \mathrm{D}$ & $\begin{array}{l}\text { Research - conducted to } \\
\text { obtain general knowledge } \\
\text { (uncertain benefits) } \\
\text { Development - } \\
\text { implementing the results } \\
\text { or research (probable } \\
\text { benefits) }\end{array}$ & $\begin{array}{l}\text { Research - conducted to } \\
\text { obtain general knowledge } \\
\text { (uncertain benefits) } \\
\text { Development - } \\
\text { implementing the results } \\
\text { or research (probable } \\
\text { benefits) }\end{array}$ & $\begin{array}{l}\text { Results of internal } \\
\text { research and } \\
\text { development held } \\
\text { for sale or obtained } \\
\text { as a result of a legal } \\
\text { action. }\end{array}$ \\
\hline Activation & Conditional & $\begin{array}{l}\text { Not permitted (exc. } \\
\text { Software with certain } \\
\text { economic feasibility) }\end{array}$ & $\begin{array}{l}\text { If held for sale or } \\
\text { obtained as a result } \\
\text { of legal action }\end{array}$ \\
\hline
\end{tabular}



Perspective.

\begin{tabular}{|c|c|c|c|}
\hline Definition & IFRS & US GAAP & CAS \\
\hline Measurement & $\begin{array}{l}\text { Purchase price, fair value, } \\
\text { reported using cost model } \\
\text { or revaluation model. } \\
\text { Amortized on systemic } \\
\text { basis. Tested for } \\
\text { impairment. }\end{array}$ & $\begin{array}{l}\text { Purchase price, fair value, } \\
\text { reported using cost model } \\
\text { only. Amortized on } \\
\text { systemic basis. Tested for } \\
\text { impairment. }\end{array}$ & $\begin{array}{l}\text { Purchase price, } \\
\text { reproduction price, } \\
\text { internal costs, } \\
\text { revaluation } \\
\text { permitted. } \\
\text { Amortized on } \\
\text { systemic basis. } \\
\text { Testing for } \\
\text { impairment not } \\
\text { specified. }\end{array}$ \\
\hline
\end{tabular}

Source: Authorial computation.

Intangibles are reported in different manners. Both the cost model and revaluation model are permitted under IFRS, whilst only the cost model is permitted under US GAAP. Intangibles with finite life are amortized over the best estimate of their useful life. These assets are tested for impairment and can be impaired. Assets with indefinite useful life are not amortized. However, they are tested at least annually for impairment.

There are assets that will never be reported on a company's balance sheet, since there are no rules for their recognition, despite their unquestionable contribution to the value of the company, such as consumer awareness, management skills, reputation, etc. This part of the company value that cannot be allocated to any reported assets will be reported as goodwill on the post-acquisition balance sheet, but will never be reported until the acquisition occurs.

It is desirable to mention that the total book value of intangibles in the case of start-up companies will be significantly lower irrespective of accounting standards. Obtaining intellectual capital on the basis of a legal act (acquisition) would be a sufficient condition of asset recognition. However, young start-up companies usually generate their intellectual capital internally. Moreover, the cost-based approach does not capture the true value of intellectual capital either, since the innovative potential gives labour and other input factors an extreme value-creating leverage.

Managerial accounting nevertheless often uses the cost base to report phantom assets - parts of the value that do not meet conditions of asset recognition and are thus not reported on a company balance sheet. Creation of a phantom asset in the managerial balance sheet must always be mirrored in the managerial profit and loss statement. Shall the company find it appropriate to classify a part of its software code as a phantom asset, it would also capitalize all the costs linked with its creation in the managerial $\mathrm{P} \& \mathrm{~L}$. Such practice requires precise evidence of 
reconciliation accounts that must explain each and every disparity between the financial and managerial statements.

\subsection{DCF}

Damodaran (2009) identifies several reasons why the DCF approach is difficult to apply on young, high growth companies. Among others he mentions the lack of history, reliance on private equity, possibly with multiple equity claims, and the general illiquidity of such an investment. Needless to say, many of such companies do not survive.

Still, DCF seems to remain the best choice, although many specifics need to be accounted for and the valuator will face several challenges such as the discount rate estimation which Festel et al. (2013) deal with by using the beta corrected by a matrix of several subjective criteria in order to fight the lack of historical data and many uncertain factors about the future.

On the other hand, acquisitions in the field of online businesses benefit from reasonably confident estimations of incremental revenues due to the precise information feedback from web analytics and automated internal procedures. Conditional to successful estimation of incremental revenues is interchangeability of technological features.

\section{Interchangeability of Technological Features Boosts Post Acquisition Revenues}

Thanks to the degree of technological advance and standardization of tools, procedures employed in one company can be acquired and serve the same purpose in a different environment. This is one of the main reasons why online company equity market is very vibrant in terms of strategic acquisitions and market consolidation.

Since partial components of the monetization process are interchangeable among companies, strategic investors can estimate potential impact of the full integration of processes executed in potential target company and the acquiring company to estimate conversion factors of the merged entity. For example, implementation of a more sophisticated search algorithm employed by the Target Company on Investor's database could immediately improve the number of bookings. Let us demonstrate the synergic effect on the following hypothetical strategic acquisition. 
Pekař, J.: Importance of Managerial Accounting from High Growth Online Company Valuation Perspective.

Tab. 4 Pre-acquisition records

\begin{tabular}{|c|c|c|c|c|c|c|c|c|}
\hline $\begin{array}{l}\text { Target } \\
\text { company }\end{array}$ & Audience & Traffic & Searches & Bookings & $\begin{array}{l}\text { Payment } \\
\text { initia- } \\
\text { tions }\end{array}$ & $\begin{array}{l}\text { Payment } \\
\text { comple- } \\
\text { tions }\end{array}$ & $\begin{array}{l}\text { Average } \\
\text { price }\end{array}$ & Sales \\
\hline \multirow{2}{*}{$\begin{array}{l}\text { Absolute } \\
\text { Conversi- } \\
\text { on factor }\end{array}$} & 5000000 & 500000 & 000 & 000 & 8000 & 600 & \multirow{2}{*}{$\begin{array}{l}100 \text { USD } \\
\text { Moneti- } \\
\text { zation }\end{array}$} & 60000 \\
\hline & & $10 \%$ & $16 \%$ & $25 \%$ & $40 \%$ & $8 \%$ & & 0.12 \\
\hline Investor & Audience & Traffic & Searches & Bookings & $\begin{array}{l}\text { Payment } \\
\text { initia- } \\
\text { tions }\end{array}$ & $\begin{array}{l}\text { Payment } \\
\text { comple- } \\
\text { tions } \\
\end{array}$ & $\begin{array}{l}\text { Average } \\
\text { price }\end{array}$ & Sales \\
\hline \multirow{2}{*}{$\begin{array}{l}\text { Absolute } \\
\text { Conversi- } \\
\text { on factor }\end{array}$} & \multirow{2}{*}{50000000} & 5000000 & 1000000 & 300000 & 100000 & 3500 & \multirow{2}{*}{$\begin{array}{l}100 \text { USD } \\
\text { Moneti- } \\
\text { zation }\end{array}$} & 350000 \\
\hline & & $10 \%$ & $20 \%$ & $30 \%$ & $33 \%$ & $4 \%$ & & 0.07 \\
\hline
\end{tabular}

Source: Authorial computation.

The investor will employ only those target company procedures that dwarf current standards of the acquiring company. This enables the acquirer to achieve the better of the two partial conversion factors value. Post-acquisition annual revenue in our model case would then be estimated as follows.

Tab. 5 Post-acquisition revenue estimation

\begin{tabular}{lllllllll}
\hline $\begin{array}{l}\text { Post- } \\
\text { Acquisi- } \\
\text { tion }\end{array}$ & Audience & Traffic & Searches & $\begin{array}{l}\text { Book- } \\
\text { ings }\end{array}$ & $\begin{array}{l}\text { Payment } \\
\text { initia- } \\
\text { tions }\end{array}$ & $\begin{array}{l}\text { Payment } \\
\text { comple- } \\
\text { tions }\end{array}$ & $\begin{array}{l}\text { Average } \\
\text { price }\end{array}$ & Revenue \\
\hline $\begin{array}{l}\text { Absolute } \\
55000000\end{array}$ & 5500000 & 1100000 & 330000 & 132000 & 9900 & 100 USD & 990000 \\
$\begin{array}{l}\text { Conversi- } \\
\text { on factor }\end{array}$ & & $10 \%$ & $20 \%$ & $30 \%$ & $40 \%$ & $8 \%$ & $\begin{array}{l}\text { Traffic } \\
\text { moneti- } \\
\text { zation }\end{array}$ & 0.18 \\
\hline
\end{tabular}

Source: Authorial computation.

Acquisition of the analysed company would thus result in incremental revenues of USD 640 thousand, which is $175 \%$ increase, although the traffic rose only by 10 $\%$. The substantial growth of sales would thus be attributable to the adoption of technical features and procedures, while most of them would for sure not be recognized as assets in the target company balance sheet. This growth is visible on the rise in traffic monetization, from 0.12 to 0.18 , which represents $50 \%$ increase. Generalizing equation 2, the revenue of an online reseller is generated as follows.

$$
T \times\left(\prod_{n=1}^{n} c f 1 \times c f 2 \times c f 3 \ldots \times c f n\right) \times A P=\text { Revenue },
$$

where $T$ stands for traffic; $c f l$ to $c f n$ stand for conversion factor 1 to conversion factor $\mathrm{n}$ and $A P$ represents the average price of a transaction.

Post-acquisition revenue of the Investor (I) after implementation of all the necessary technological features from the Target company (T) as described above would be computed as follows. 


$$
\begin{gathered}
\left(T_{I}+T_{T}\right) \times\left(\prod_{n=1}^{n} \max \left[c f 1_{I} ; c f 1_{T}\right] \times \max \left[c f 2_{I} ; c f 2_{T}\right] \times \max \left[c f 3_{I} ; c f 3_{T}\right] \times \ldots \times\right. \\
\left.\max \left[c f n_{I} ; c f n_{T}\right]\right) \times A P=\text { Revenue },
\end{gathered}
$$

where TI and TT stand for traffic of the investor and the target company, respectively; cf1I to cfnI represent conversion factors 1 to $\mathrm{n}$ for the investor; cf1T to cfnT represent conversion factors 1 to $\mathrm{n}$ recorded by the target company and AP represents the average price of a transaction.

Thus, the incremental revenue would be easily computed as

$$
\begin{gathered}
\text { Incremental revenue }= \\
\text { Post acquisition revenue - Base scenario Investor's revenue, }
\end{gathered}
$$

Using logical estimation and best practices of financial modelling, an investor can estimate the impact of incremental revenue on the company's profit, deriving incremental profit and cash flow of the potential acquisition for a desirable time period. Using further estimates, the acquirer can make a post-acquisition financial plan, which would then be compared with the base financial plan to arrive at the incremental financial plan. With the incremental financial plan, DCF methods can be applied.

Despite precise metrics and other prediction tools, $70 \%$ of mergers failed to achieve estimated revenue synergies and 39\% failed to achieve estimated cost-side synergies in the study performed by McKinsey \& Company (Christofferson et al. 2014). Moreover, the study showed that 2 to 5 per cent of the combined customer base was cannibalized.

The CF projected by target companies significantly differs from the postacquisition incremental $\mathrm{CF}$, resulting in a large difference between the value of the target company for its current shareholders and for the potential investor. Such differences makes the innovative base and leverage potential of technologies and/or procedures the subject to an acquisition. The bigger the difference in value, the higher the leverage.

\section{Conclusion}

The true value of young, high growth online companies cannot be derived from commonly available financial data and statements, as shown on the example of an online reseller of air tickets. Companies often record operating losses, which impedes applicability of a valuation based on the peer comparison and market multiples. intellectual capital that generates the company value does not meet requirements for an asset recognition under any common accounting standard and thus the asset-based approach hardly represents a satisfactory valuation technique. Applicability of the DCF method is usually jeopardized by the nature of 

Perspective.

companies under examination, such as already mentioned negative earnings, low asset base, reliance on private equity, illiquidity, and risky environment.

Managerial accounting must be paid special attention to when assessing the value of a young, high growth online company powered by intellectual capital. Bounded by best practices rather than rigid standards, well-kept managerial accounting provides much more precise hands-on information about the given company on the true substance-over-form principle.

Managerial accounting statements usually recognize phantom assets to account for value internally created by the company that does not meet requirements for asset recognition under the adopted accounting framework. Accompanied by the respective reconciliation accounts, managerial statements provide users of information with a more precise description of the business conditions and also allow for the peer comparison, despite possible discrepancy of different accounting frameworks or different asset origins (purchase/legal act vs. internal generation). Managerial accounting statements typically report higher amounts of assets and higher EBITDA compared to financial statements. An alternative approach based on the sum of recognized and phantom assets could then be introduced into the valuation matrix.

Detailed managerial accounting also allows for an application of DCF in the case of strategic acquisitions. Interchangeability of technological features and best practices also allow the Investor to calculate impact of the acquisition under consideration and subsequently value the target company applying the DCF valuation of post-acquisition incremental cash flows.

Key metrics necessary for such an approach to valuation are value drivers with impacts predictable via conversion factors within the online industry. Such conversion factors explain the ratio of completed transactions and theoretically executable transactions arising from the size of the customer base. Total conversion factor is a product of several partial conversion factors. Conversion factors are recorded with extreme precision, since every action of a website visitor is recorded and then displayed anytime using the web analytical tools that all online businesses use.

Non-financial metrics play crucial role in young, high growth online company valuation, despite common damnation following the dot.com bubble burst. The importance of managerial accounting is very often dwarfing the importance of financial data and therefore needs to be recorded with a diligence and precision.

Some practices employed within the managerial accounting might be useful for further discussions on the appropriateness of today's accounting standards, especially from the perspective of the substance-over-form principle, a topic that is often addressed in the author's research. 


\section{References}

Alexander, C. P., 1983. The New Economy. 30 May 1983. Available from: <http://content.time.com/time/magazine/article/0,9171,926013, 00.html>. [3 January 2017].

Bassi, L. J., 1997. Harnessing the Power of Intellectual Capital. Training \& Development 12, 25-30.

Birch, D. G. W., 1979. The Job Generation Process. MIT Program on Neighborhood and Regional Change 302 . Available from: <https://ssrn.com/ abstract $=1510007>$. [3 January 2017].

Berger, S., 2005. Great Age Guide to the Internet. Que Corp., Indianapolis.

Cardoza, K., Basara, J., Cooper, L., Conroy, R., 2006. The Power of Intangible Assets: An Analysis Of The S\&P 500. Atlanta, LESI. Available from: <https:// www.lesi.org/les-nouvelles/les-nouvelles-online/2006/march-2006/201 1/08/08/the -power-of-intangible-assets-an-analysis-of-the-s-p-500->. [3 January 2017].

Christofferson, S. A., McNish, R. S., Sias, D. L., 2004. Where Mergers Go Wrong. McKinsey Quarterly. Available from: <http://www.mckinsey.com/businessfunctions/strategy-and-corporate-finance/our-insights/where-mergers-go-wrong> . [21 December 2016].

Damodaran, A., 2009. Valuing Young, Start-up and Growth Companies: Estimation Issues and Valuation Challenges. SSRN Electronic Journal. DOI: 10.2139/ssrn.1418687.

Demers, E., Lev, B., 2001. A Rude Awakening: Internet Shakeout in 2000. Review of Accounting Studies 2, 331-359. DOI: 10.2139/ssrn.1418687.

Festel, G., Wuermseher, M., Cattaneo, G. 2013. Valuation of Early Stage Hightech Start-up Companies. International Journal of Business 3, 217- 231.

Gupta, J., Chevalier, A., 2002. The Valuation of Internet Companies: The Real Options Approach. Houston, Asia Pacific Decision Sciences Institute. Available from: <http://iceb.nccu.edu.tw/proceedings/APDSI/2002/papers/paper19 .pdf>. [3 January 2017].

Gupta, S., Lehmann, R. D., Stuart, J. A., 2004. Valuing Customers. Journal of Marketing Research 1, 7-18. DOI: 10.2139/ssrn.459595.

Higson, C., Briginshaw, J., 2000. Valuing Internet Businesses. Business Strategy Review 1, 10-20. DOI: 10.1111/1467-8616.00125.

Ofek, E., Richardson, M., 2001. Dotcom Mania: The Rise and Fall of Internet Stock Prices. NBER Working Paper 8630, National Bureau of Economic Research, Cambridge. DOI: 10.3386/w8630. 
Pekař, J.: Importance of Managerial Accounting from High Growth Online Company Valuation Perspective.

Rosner, S., 2013. Understanding Internet Valuation. The Journal of Private Equity 1, 31-38. DOI: 10.3905/jpe.2000.319975.

Shapiro, C., Varian, H., 1998. Information Rules: A Strategic Guide to the Network Economy. Harvard Business Review Press, Boston.

Soto-Acosta, P., Meroño-Cerdan, A. L., 2008. Analyzing E-Business Value Creation from a Resource-Based Perspective. International Journal of Information Management 1, 49-60. DOI: 10.1016/j.ijinfomgt.2007.05.001.

Vydržel, K., Soukupová, V., 2012. Empirical Examination of Valuation Methods Used in Private Equity Practice in the Czech Republic. Journal of Private Equity 1, 83-99.

Zörgiebel, S. J., 2016. Valuation of IPOs with Negative Earnings. SSRN Electronic Journal. DOI: 10.2139/ssrn.2698281.

Zwilling, M. C., 2016. Ten Top Techniques for Startup Valuations. Fountain Hills, Startup Professionals. Available from: <http://www.startupprofessionals.com/lin ked/ten\%20top\%20techniques\%20for\%20startup\%20valuation.ppd>. [3 January 2017]. 